\title{
Viljanviljelijöiden sopeutuminen EU:n hintasuhteisiin
}

\author{
Henrik Antas ${ }^{1}$, John.Sumelius ${ }^{2}$ \\ ${ }^{1}$ MMM:n tietopalvelukeskus (TIKE),PL 310,00023 Valtioneuvosto,henrik.antas@mmm.fi \\ ${ }^{2}$ Taloustieteen laitos, PL 27, 00014 Helsingin yliopisto, john.sumelius @helsinki.fi
}

\section{Johdanto}

Suomen liittyminen Euroopan unioniin merkitsi huomattavaa muutosta maatalouden toimintaympäristössä. Vuonna 1995 viljan tuottajahinnat alenivat huomattavasti, noin 50-60 prosenttia verrattuna edelliseen vuoteen (Kettunen 1997). Maatalouden tuotantopanoshintaindeksi pieneni samaan aikaan noin $20 \%$. Hinnan alennuksia korvattiin osittain pinta-alaan sidotuilla tuilla, joiden suuruus määräytyy mm. tilan tukialueen perusteella. Uusi toimintaympäristö aiheutti muutoksia tilan tuloksen kannalta merkittävie n tekijöiden keskinäisiin suhteisiin. Tuotantopanosten optimi muuttui vähemmän voimaperäiseksi. Konekustannukset näyttivät tärkeämpää roolia ja sopivan konekannan optimoinnista tuli entistä tärkeämpää. Koneyhteistyön merkitys kasvoi. Investointitukien kautta pystytään alentamaan kone- ja rakennuskustannuksia.

Mitkä yrittäjät sopeutuivat parhaiten uuteen tilanteeseen? Voidaan ajatella kaksi vaihtoehtoista vastausta: 1. Viljatilat, joiden tulos oli parempi kuin keskimäärin ennen 1995 ovat edelleen kannattavimmat tilat. 2. Vanhan hyvän tuloksen tehneet tilat eivät ole kannattavimpia enää EU-Suomessa, jonka toimintaympäristö vaatii toisenlaisia toimenpiteitä kuin ennen EU-kautta. Lisäksi voidaan kysyä minkälaiset viljanviljelijät tuottavat tänä päivän parhaimman tuloksen? Saadakseen vastauksen edelliseen kysymykseen esitettiin seuraavat yksilöidyt tutkimuskysymykset, jotka koskivat Etelä-Suomen viljatilojen sopeutumista EU-aikaan:

1. Kuinka katetuotot $A, B$ ja $C$ ja eri kustannuserät kevätvehnän, rehuohran ja rypsin viljelyssä ovat kehittyneet vuosina 1991-1999?

2. Mitkä tekijät selittävät korkeimpien ja matalimpien katetuottojen erot?

3. Onko niillä tiloilla, joilla oli korkeimmat katetuotot ennen EU-liittymistä edelleen korkeimmat katetuotot EU-liittymisen jälkeen? Kuinka suuri on vuotuinen katetuoton vaihtelu?

4. Kuinka sopeutuminen EU-aikaan on tapahtunut niillä tiloilla jotka ovat sopeuttaneet tuotantonsa parhaiten?

\begin{abstract}
Aineisto ja menetelmät
Aineistona käytettiin Nylands Svenska Lantbrukssällskapetin (maanviljelysseura) nk. intensiivineuvonnan tiloja, joilta on saatavana lohkokohtaista aineistoa eri viljelykasvien kustannuskomponenteista, tuotoista ja tuista. Tilojen määrä on vv. 1991-1999 vaihdellut 94 ja 124 välillä. Tilojen vilja -ala on Suomen keskikokoa suuremmat sillä näiden tilojen keskikoko oli v. 1991 89,5 ha ja vuonna 1999 114,5 ha. Suurin osa sijaitsee A-tukialueella mutta muutama B-tukialueella. Katetuotto A on kokonaistuotto vähennettynä muuttuvilla kustannuksilla, katetuotto B on katetuotto $\mathrm{A}$ edelleen vähennettynä viljelijäperheen oman työn kustannuksella ja katetuotto $\mathrm{C}$ on katetuotto $\mathrm{B}$ edelleen vähennettynä yleiskustannuksella (liikkeen johto, ojituksen vuotuiskustannus, teiden ja siltojen ylläpitokustannus, kalustokustannus, auto, puhelin yms.) ja kiinteillä kustannuksilla (koneiden ja rakennusten poisto ja ylläpito, vakuutus). Korkeimman katetuoton saavuttaneiden tilojen katetuottoja ennen EU-liittymistä ja sen jälkeen tutkittiin nk. $\chi^{2}$-testillä.
\end{abstract}

\section{Tulokset}

Katetuotot laskivat voimakkaasti EU-liittymisen jä lkeen johtuen hintamuutoksista. Kevätvehnän ja rehuohran katetuotot A, B ja C pinta-alatuet mukaan lukien on esitetty kahden kauden osalta taulukossa 1. Taulukko 1. Kevätvehnän, rehuohran ja rypsin katetuotto tutkituilla tiloilla 1991-1994 ja 1995-1999, $\mathrm{mk} / \mathrm{ha}$ (Antas 2002)

\begin{tabular}{|l|l|l|l|}
\hline & Katetuotto A & Katetuotto B & Katetuotto C \\
\hline Kevätvehnä 1991-1994 & 6928 & 6284 & 1352 \\
\hline Kevätvehnä 1995-1999 & 4720 & 4043 & 478 \\
\hline Rehuohra 1991-1994 & 5751 & 5070 & 18 \\
\hline Rehuohra 1995-1999 & 3585 & 2877 & -781 \\
\hline Rypsi 1991-1994 & 5924 & 5292 & 405 \\
\hline Rypsi 1995-1999 & 3547 & 2987 & -418 \\
\hline
\end{tabular}


Kevätvehnä on ainoa kasvi, joka antoi positiivisen katetuoton C EU-liittymisen jälkeen vaikka tuet otetaan huomioon. Kevätvehnän hehtaarisato laski huomattavan paljon vähemmän kuin ohran ja rypsin hehtaarisato vaikka tuotantokustannukset suhteellisesti laskivat yhtä paljon kaikilla kolmella viljelykasveilla. Tämän perusteella voidaan todeta, että kevätvehnän viljelyssä on ollut paremmat mahdollisuudet säästää kustannuksissa kuin ohran ja rypsin viljelyksessä. Pinta-alatuen osuus tuotoista oli 6,6 \% ennen EU-jäsenyyttä ja 41,6 \% vv. 1995-1999. Rehuohran katetuotto C oli $-781 \mathrm{mk} / \mathrm{ha}$ ja rypsin $-418 \mathrm{mk} / \mathrm{ha}$ jälkimmäisellä tarkastelukautena. Pinta-alatuen osuus oli rehuohran osalta 8,3\% ennen 1995 ja 49,6 vv. 1995-1999. Rypsin vastaavat luvut olivat 6,4\% ja 61,9\%.

Tutkimuksessa tarkasteltiin lähemmin kevätvehnän katetuottoa määrittävät tilakohtaiset tekijät. Voidaan todeta, että tilan vilje lyalan suuruus ja katetuoton $C$ välillä ei löytynyt paljokaan yhteyttä. Tilan suuruus ei näytä vaikuttavan katetuottoon C. Tilakohtainen tarkastelu kuitenkin paljastaa, että korkeimman katetuoton saavuttaneilla tiloilla lähes kaikki kustannuskomponentit olivat alhaisemmat kuin muiden tilojen vastaavat kustannukset. Tästä huolimatta niiden hehtaarisadot olivat korkeampia. Korkea katetuotto C korreloi korkean sadon kanssa mutta kustannukset näyttävät silti olevan alhaisempia. Taulu kossa 2 on esitetty muuttuvia kustannuksia ja joitakin eriä parhaimman ja heikoimman katetuoton C omaavilla tiloilla vuonna 1997.

Taulukko 2. Muuttuvien kustannusten ero parhaimmalla ja heikoimmalla neljänneksellä, v. 1997 (Antas 2002)

\begin{tabular}{|c|c|c|c|c|c|c|c|}
\hline & $\begin{array}{l}\text { Muuttuvat } \\
\text { kustannuk- } \\
\text { set mk/ha }\end{array}$ & $\begin{array}{l}\text { Muuttuvat } \\
\text { kustannuk- } \\
\text { set mk/kg }\end{array}$ & $\begin{array}{l}\text { Lannoitus- } \\
\text { kustannus, } \\
\mathrm{mk} / \mathrm{ha}\end{array}$ & $\begin{array}{l}\text { Lannoitus- } \\
\text { kustannus, } \\
\mathrm{mk} / \mathrm{kg}\end{array}$ & $\mathrm{N} \mathrm{kg/ha}$ & $\mathrm{P} \mathrm{kg} / \mathrm{ha}$ & $\begin{array}{l}\mathrm{K} \\
\mathrm{kg} / \mathrm{ha}\end{array}$ \\
\hline Paras $25 \%$ & 1858 & 0,39 & 597 & 0,13 & 122,4 & 13,2 & 13,9 \\
\hline $\begin{array}{l}\text { Heikoin } \\
25 \%\end{array}$ & 2002 & 0,50 & 617 & 0,15 & 127,1 & 13,7 & 16,5 \\
\hline -Ero \% & $7,8 \%$ & $19,0 \%$ & $3,4 \%$ & $15,4 \%$ & $3,8 \%$ & $3,8 \%$ & $28,7 \%$ \\
\hline & $\begin{array}{l}\text { Siemen } \\
\mathrm{kg} / \mathrm{ha}\end{array}$ & $\begin{array}{l}\text { Siemenkust. } \\
\mathrm{mk} / \mathrm{ha}\end{array}$ & $\begin{array}{l}\text { Siemenkust. } \\
\mathrm{mk} / \mathrm{kg}\end{array}$ & $\begin{array}{l}\text { Kalkitusk. } \\
\mathrm{mk} / \mathrm{ha}\end{array}$ & $\begin{array}{l}\text { Kalkit.k. } \\
\mathrm{mk} / \mathrm{kg}\end{array}$ & $\begin{array}{l}\text { Kuivatusk. } \\
\mathrm{mk} / \mathrm{ha}\end{array}$ & $\begin{array}{l}\text { Trakt.k } \\
. \mathrm{mk} / \mathrm{ha}\end{array}$ \\
\hline Paras 25\% & 270 & 360 & 0,08 & 124 & 0,03 & 93 & 101 \\
\hline Heikoin 25\% & 273 & 405 & 0,10 & 235 & 0,06 & 134 & 106 \\
\hline -Ero \% & $1,1 \%$ & $12,5 \%$ & $25,0 \%$ & $89,5 \%$ & $100 \%$ & $44,1 \%$ & $5 \%$ \\
\hline
\end{tabular}

Erot kilokohtaisissa siemenkustannuksissa parhaimman ja heikoimman neljänneksen välillä olivat $25 \%$ ja kalkituskustannuksen osalta jopa $100 \%$. Erot kuivatuskustannusten osalta olivat isot, $44,1 \%$. Traktorikustannuksissa ei näyttänyt olevan suuria eroja. Työkustannuksissa oli jonkin verran eroja. Hehtaarikohtais issa työkustannuksissa löytyi eroja, 10,9\% ja kilokohtaisissa 28,6\%. Taulukossa 3 on esitetty ero kiinteiden kustannusten ja yleiskustannusten osalta.

Taulukko 3.Kiinteiden ja yleiskustannusten ero parhaimmalla ja heikoimmalla neljänneksellä v. 1997, (Antas 2002)

\begin{tabular}{|l|l|l|l|l|l|l|}
\hline & $\begin{array}{l}\text { Kiinteät ja } \\
\text { yleiskustan- } \\
\text { nukset mk/ha }\end{array}$ & $\begin{array}{l}\text { Kiinteät ja } \\
\text { yleiskustan- } \\
\text { nukset mk/kg }\end{array}$ & $\begin{array}{l}\text { Konekus- } \\
\text { tannus, } \\
\text { mk/ha }\end{array}$ & $\begin{array}{l}\text { Konekus- } \\
\text { tannus, } \\
\mathrm{mk} / \mathrm{kg}\end{array}$ & $\begin{array}{l}\text { Rakennus- } \\
\text { kustannus, } \\
\mathrm{mk} / \mathrm{ha}\end{array}$ & $\begin{array}{l}\text { Rakennus- } \\
\text { kustannus, } \\
\mathrm{mk} / \mathrm{kg}\end{array}$ \\
\hline Paras 25\% & 2864 & 0,61 & 1103 & 0,23 & 254 & 0,05 \\
\hline Heikoin 25\% & 3853 & 0,94 & 1902 & 0,46 & 376 & 0,09 \\
\hline -Ero \% & $36 \%$ & $54,1 \%$ & $72,4 \%$ & $100 \%$ & $48,0 \%$ & $80,0 \%$ \\
\hline & & & & & & \\
\hline & $\begin{array}{l}\text { Yleiskustan- } \\
\text { nus, mk/ha }\end{array}$ & $\begin{array}{l}\text { Yleiskustan- } \\
\text { nus, mk/kg }\end{array}$ & $\begin{array}{l}\text { Maakust. } \\
\text { mk/ha }\end{array}$ & $\begin{array}{l}\text { Maakust. } \\
\text { mk/kg }\end{array}$ & & \\
\hline Paras 25\% & 842 & 0,18 & 665 & $0,14 \%$ & & \\
\hline Heikoin 25\% & 882 & 0,22 & 693 & $0,18 \%$ & & \\
\hline -Ero \% & $4,8 \%$ & $22,2 \%$ & $4,2 \%$ & $28,6 \%$ & & \\
\hline
\end{tabular}

Merkittävimmät erot löytyi kustannuksissa odotetusti kiinteissä kustannuksissa, joiden kilokohtainen kokonaisero oli noin 54\% parhaimman ja heikoimman neljänneksen välillä. Konekustannus kiloa kohti 
oli kaksi kertaa suurempi heikoimman $25 \%$ katetuoton ryhmässä verrattuna parhaimman $25 \%$ katetuoton ryhmässä. Rakennuskustannusten osalta oli $80 \%$ ero ryhmien välillä. Yhteenvetona kustannustarkastelusta voidaan todeta, että hehtaarisadolla ja kiinteillä kustannuksilla, varsinkin konekustannuksilla on suuri vaikutus katetuottoon. Positiivisen tuloksen saavuttamiseksi kaikki viljelytoimenpiteet on harkittava huolellisesti.

Edelleen haluttiin vastata kysymykseen onko niillä tiloilla, joilla oli korkeimmat katetuotot ennen EU-liittymistä edelleen korkeimmat katetuotot EU-liittymisen jälkeen? $\chi^{2}$-testin perusteella ei löydetty merkitsevää yhteyttä yksittäisten tilojen tuloksissa kahden mainitun ajanjakson välillä. Näin ollen voidaan todeta, että ei ole löydettävissä tilajoukkoa, jonka tulos olisi ollut paras ennen EUjäsenyyttä ja EU liittymisen jälkeen. Vuosittainen hehtaarisatovaihtelu näyttää olevan liian suuri. On toisin sanoen vaikea löytää sellainen tilajoukko, joka olisi edustanut parasta tulosta tekevää neljännestä ennen EU-jäsenyyttä ja EU:hun liittymisen jälkeen. Samalla voidaan todeta, että EU-jäsenyys vaikutti eniten tehokkaimpiin tiloihin, joiden katetuotot laskivat enemmän kuin keskimäärin EUjäsenyyden aikana.

\section{Johtopäätökset}

EU:hun liittymisen jälkeen katetuotot laskivat voimakkaasti. Katetuotto C pysyi tutkituilla tiloilla positiivisena tarkastelujakson lopussa ainoastaan kevätvehnän osalta. Katteen C ja viljelyalan välillä ei löydetty paljoakaan yhteyttä joten tilakoosta johtuvia skaalatuottoja ei löytynyt (on kuitenkin muistettava, että tilojen keksikoko vuonna 1999 oli 114,5 ha). Tiloilla joilla oli korkein kate C satotaso oli selväsi korkeampi mutta kustannukset silti matalampia. Näyttää siltä, että parhaimman katteen tehneet tilat pystyvät tuottamaan korkean sadon kuitenkin tuotantokustannuksia samalla hyvin halliten. Tilajoukkoa, joka olisi osoittautunut parhaimmaksi ennen vuotta 1995 ja sen jälkeen ei löytynyt. Sääeroista johtuvat vaihtelut ovat todennäköisesti liian suuret, jotta tällaista ryhmää löydettäisiin.

\section{Kirjallisuus :}

Antas, H. 2002. Anpassningen av spannmåls- och rybsodlingen till prisförhållanden inom EU på gårdar i Nyland. Pro gradu-tutkielma taloustieteen laitos 72 s. + liitteet.

Kettunen, L. 1998. Suomen maatalous 1997. Maatalouden taloudellisen tutkimuslaitoksen julkaisuja 86. 54 s. + liitteet 